\title{
KONSEP FISKAL ISLAM DALAM PERSPEKTIF HISTORIS
}

\author{
Ali Murtadho, IAIN Walisongo Semarang
}

\begin{abstract}
Fiscal policy is not synonymous with Islam taxation / tribute that made the king / emperor , nor synonymous with modern fiscal policy born of the failure of the free market mechanism. Referring to public finance policy at the beginning of the Islamic era, Islamic fiscal policy is a practical representation of the mission of the Islamic economic system oriented religiosity, justice and wealth distribution.

Not only deal with the fiscal revenue and expenditure of state revenue but also about the mission of fair distribution of wealth. Jizya, kharaj and ghanimah is a fiscal instrument in accordance with the circumstances at that time for the mission fair distribution of wealth. Based on the concept of fiscal Islam, then the application of fiscal policy now must somehow form could lead to a fair distribution of wealth towards a comprehensive community welfare ( falah), not just the budget deficit.
\end{abstract}

Kata Kunci : Fiskal, Instrumen Fiskal, Baitul Mal, Distribusi Kekayaan

\section{Pendahuluan}

Dalam konsep Islam pemerintah bertanggung jawab atas kesejahteraan kehidupan seluruh warganya di berbagai bidang, terutama bidang ekonomi yang menjadi tulang punggung kehidupan. Campur tangan negara dalam masalah ekonomi yang pernah diperdebatkan antara antara kapitalis dan sosialis, dalam Islam adalah satu bentuk tanggung jawab negara yang sudah semestinya untuk menjamin kemaslahatan rakyat. Bahkan kini campur tangan negara yang lebih spesifik bernama kebijakan fiskal tidak bisa dihindarkan oleh negara manapun termasuk yang menganut sistem kapitalis atau pasar bebas.

Keberhasilan Rasulullah SAW dalam membangun negara yang berpusat di Madinah dari bekal nol menjadi negara yang memiliki kestabilan ekonomi yang mantap menunjukkan keberhasilan sistem fiskal yang diterapkan waktu itu. Rasulullah SAW telah dapat memainkan kebijakan fiskalnya secara tepat 
Konsep Fiskal Islam dalam Perspektif Historis

dengan mempertimbangkan berbagai faktor determinan ekonomi waktu itu. Sebagaimana disadari bersama faktor-faktor determinan ekonomi saat ini telah banyak berbeda dengan yang dihadapi pada waktu Rasulullah SAW. Bagaimanapun kehidupan ekonomi telah melewati rentangan waktu yang panjang dengan berbagai dinamika sosial, budaya daan politik yang selalu mengiringinya. Persoalan bagaimana rumusan sistem fiskal yang Islami dan bagaimana ketepatan penerapannya menjadi sebuah kajian yang tidak mudah untuk dipecahkan. Makalah sederhana ini hanya akan menelaah konsep dan historisitas kebijakan fiskal Islam yang mengacu pada masa awal Islam.

\section{Sekilas tentang Kebijakan Fiskal dan Peranannya}

Dalam wacana ekonomi makro, kebijakan fiskal diartikan sebagai langkah-langkah pemerintah untuk membuat perubahan-perubahan dalam sistem pajak atau dalam perbelanjaannya yang bertujuan mengatasi masalahmasalah ekonomi yang dihadapi. ${ }^{1}$ Kebijakan fiskal merupakan instrumen manajemen permintaan (demand management) yang berusaha mempengaruhi tingkat aktivitas ekonomi melalui pengendalian pajak dan pengeluaran pemerintah. ${ }^{2}$ Kebijakan fiskal diarahkan untuk mencapai kesejahteraan, yang dalam perekonomian sekuler didefinisikan sebagai maksimalisasi bagi benefit individu dalam kehidupan. Fiskal terutama ditujukan untuk mencapai alokasi sumber daya secara efisien, stabilisasi ekonomi, pertumbuhan dan distribusi pendapatan serta kepemilikan. ${ }^{3}$ Langkah-langkah fiskal dipandang efektif untuk mengatasi problematika perekonomian seperti inflasi di samping langkah-langkah moneter.

Perhatian serius terhadap kebijakan fiskal dalam wacana ekonomi konvensial baru disadari belakangan yakni setelah dekade 1930-an. Sebelumnya para ahli ekonomi konvensional yang tergolong mazhab klasik (ahli ekonomi

1 Sadono Sukirno, Makroekonomi Teori Pengantar, Edisi Ketiga, Jakarta : PT RajaGrafindo Persada, 2006, hlm. 184

${ }^{2}$ Christopher Pass \& Bryan Lowes, Collins Dictionary of Economics, terj. Tumpal Rumapea \& Posman Haloho, "Kamus Lengkap Ekonomi", Edidi Kedua, Jakarta: Penerbit Erlangga, 1994, hlm. 232. hlm. 9 .

${ }^{3}$ Mustafa Edwin Nasution, et.al., Pengenalan Ekslusif Ekonomi Islam, Jakarta: Kencana, 2007, 
yang hidup antara zaman Adam Smith (1776) dan zaman Keynes (1936) tidak benyak menganalisis tentang pentingnya kebijakan fiskal dalam mengatasi masalah ketidakstabilan ekonomi dan pertumpuhan ekonomi. Kurang adanya perhatian tersebut disebabkan adanya keyakinan mereka bahwa sistem pasar bebas akan mewujudkan tingkat kegiatan ekonomi yang efisien dalam jangka panjang. Meskipun ketidakstabilan perekonomian yang menyebabkan kemunduran ekonomi dan pengangguran dapat berlaku dalam setiap perekonomian, tetapi menurut mereka masalah-masalah tersebut hanya sementara karena sistem pasar bebas akan membuat penyesuaian-penyesuaian yang menyebabkan masalah-masalah tersebut akan lenyap dengan sendirinya dan pertumbuhan ekonomi yang kuat akan berlangsung kembali. Namun dengan terjadinya great depression di Amerika Serikat tahun 1929-1932 di mana seperempat dari tenaga kerja di Amerika Serikat menganggur dan pendapatan nasionalnya merosot tajam ahli-ahli ekonomi sadar bahwa mekanisme pasar tidak dapat secara otomatis menimbulkan pertumbuhan ekonomi yang baik. Kondisi ini mendorong seorang John Maynard Keyness mengemukakan pandangan baru yang berbeda dengan para ahli ekonomi sebelumnya. ${ }^{4}$ Keynes mengkritik keyakinan ahli-ahli ekonomi klasik bahwa penggunaan tenaga kerja penuh dan pertumbuhan ekonomi yang kuat selalu dapat dicapai. Keynes berpendapat pengeluaran agregat, yaitu pembelanjaan masyarakat terhadap barang dan jasa, adalah faktor utama yang menentukan tingkat kegiatan ekonomi yang dicapai sesuatu negara. Menurut Keynes diperlukan kebijakan pemerintah untuk menciptakan kestabilan dan pertumbuhan ekonomi yang mantap. Salah satu bentuk dari campur tangan pemerintah yang dapat dilakukan adalah menjalankan kebijakan fiskal. ${ }^{5}$

Kebijakan fiskal terkait dengan kebijakan yang mempengaruhi anggaran pendapatan dan belanja suatu negara. di samping kebijakan ekonomi lainnya seperti kebijakan moneter dan perdagangan, kebijakan fiskal diperlukan untuk mengoreksi gangguan-gangguan yang menghambat jalannya roda

4 Pandangan tersebut dikemukakan dalam bukunya yang berjudul The General Theory of Employment, Interest and Money dan diterbitkan pada tahun 1936 yang akhirnya menjadi landasan bagi teori makroekonomi modern. Lihat : Sadono Sukirno, Makroekonomi Teori Pengantar, Jakarta : PT RajaGrafindo Persada, 2006, hlm. 7. Lihat pula : Adam Kuper dan Jessica Kuper, The Social Science Encyclopedia, second edition, New York : Routledge, 2001, hlm. 439-440.

${ }^{5}$ Sadono Sukirno, Op.Cit., hlm. 7, 85 dan 184.. 
perekonomian. Sistem ekonomi kapitalis/sistem ekonomi pasar sangat tergantung pada berjalannya mekanisme pasar. Karenanya jika terjadi gangguan-gangguan terhadap jalannya mekanisme pasar maka diperlukan berbagai macam usaha untuk mengoreksi jalannya perekonomian agar mekanisme pasar dapat berjalan secara sempurna. ${ }^{6}$

Kebijakan fiskal yang berarti campur tangan pemerintah terhadap perekonomian diharapkan dapat berpengaruh pada proses penentuan keseimbangan pendapatan nasional dimana pajak akan mengurangi pengeluaran agregat melalui pengurangan konsumsi rumah tangga dan pajak juga memungkinkan pemerintah melakukan perbelanjaan yang berarti perbelanjaan agregat. Di samping itu campur tangan pemerintah dalam perekonomian akan menimbulkan tiga jenis aliran pendapatan dan pengeluaran: Pertama, aliran pendapatan pemerintah dari pembayaran pajak oleh rumah tangga dan perusahaan. Kedua, aliran pengeluaran pemerintah ke sektor perusahaan yang merupakan nilai pengeluaran pemerintah atas barangbarang dan jasa-jasa yang diproduksi perusahaan. Ketiga, aliran pendapatan dari sektor rumah tangga dari pemerintah. Secara umum, pemungutan pajak akan mengakibatkan konsumsi dan tabungan rumah tangga berkurang. ${ }^{7}$

Pajak merupakan sumber utama perbelanjaan pemerintah. Sebagian dari pengeluaran pemerintah untuk membiayai administrasi pemerintahan dan sebagian lainnya untuk membiayai kegiatan-kegiatan pembangunan, membayar gaji pegawai-pegawai pemerintah, membiayai sistem pendidikan dan kesehatan rakyat, membiayai perbelanjaan untuk angkatan bersenjata, dan membiayai berbagai jenis infrastruktur yang penting artinya dalam pembangunan. Perbelanjaan-perbelanjaan tersebut akan meningkatkan pengeluaran agregat dan mempertinggi tingkat kegiatan ekonomi negara. ${ }^{8}$

Dalam kajian ekonomi makro, jumlah pengeluaran pemerintah yang akan dilakukan dalam suatu periode tertentu tergantung kepada banyak faktor. Yang penting di antaranya adalah jumlah pajak yang akan diterima, tujuan-tujuan kegiatan ekonomi jangka pendek dan pembangunan ekonomi jangka panjang, dan pertimbangan politik dan keamanan. Pendapatan nasional tidak memegang

\footnotetext{
${ }^{6}$ Mustafa Edwin Nasution, et.al., Op.Cit., hlm. 203-204.

${ }^{7}$ Sadono Sukirno, Op.Cit., hlm. 150-151, 155, 160.

8 Ibid., hlm. 168.
} 
peranan yang penting dalam menentukan perbelanjaan pemerintah. Dalam masa kemunduran ekonomi, misalnya pendapatan pajak berkurang. Tetapi untuk mengatasi pengangguran pemerintah perlu lebih banyak menggalakkan program-program pembangunan, maka pengeluaran pemerintah perlu ditambah. Sebaliknya, pada waktu inflasi dan tingkat kemakmuran tinggi, pemerintah harus lebih berhati-hati dalam perbelanjaannya. Harus dijaga agar pengeluaran pemerintah tidak memperburuk keadaan inflasi yang berlaku. ${ }^{9}$

Wewenang kebijakan fiskal (biasanya diemban Departemen Keuangan) menyangkut berbagai kebijakan perpajakan untuk mengatur permintaan agregat. Pengeluaran pajak langsung atas individu (pajak pendapatan) dan pajak perusahaan dapat dapat ditingkatkan atau diturunkan. Misalnya untuk mengatur inflasi, dengan meningkatkan pajak pendapatan akan mengurangi pendapatan disposibel masyarakat, demikian juga dengan meningkatkan pajak perusahaan akan mengakibatkan perusahaan mempunyai keuntungan yang lebih kecil yang yang bisa dibagikan dalam bentuk dividen dan reinvestasi. Pengeluaran masyarakat juga dapat dikurangi dengan meningkatkan pajak tidak langsung seperti pajak pertambahan nilai secara umum, atau pajak bea cukai atas produk-produk tertentu semisal bahan bakar dan rokok. Dengan cara menaikkan harga produk akan berakibat pada suatu penurunan dalam daya beli. ${ }^{10}$

Kebijakan fiskal yang terutama digunakan pemerintah untuk mengatasi masalah-masalah ekonomi yang sedang dihadapi (kebijakan fiskal diskresioner/discretionary fiscal policy) mencakup langkah-langkah pemerintah untuk mengubah pengeluarannya atau pemungutan pajaknya dengan tujuan untuk mengurangi gerak naik turun tingkat kegiatan ekonomi dari waktu ke waktu dan menciptakan suatu tingkat kegiatan ekonomi yang mencapai tingkat konsumsi tenaga kerja yang tinggi, tidak menghadapi masalah inflasi, dan selalu mengalami pertumbuhan yang memuaskan. Ada dua macam cara yang digunakan oleh pemerintah untuk menjalankan kebijakan tersebut yaitu membuat perubahan-perubahan atas pengeluarannya dan membuat perubahan-perubahan atas pajak yang dipungutnya. Dalam pelaksanaannya

${ }^{9}$ Ibid., hlm. 168-169.

${ }^{10}$ Christopher Pass \& Bryan Lowes, Op.Cit., hlm. 232. 
kedua kebijakan fiskal diskresioner ini dapat digunakan secara tersendiri atau digabungkan. Dengan demikian kebijakan fiskal diskresioner dapat dibedakan dalam tiga bentuk, yaitu membuat perubahan ke atas pengeluaran pemerintah, membuat perubahan ke atas sistem pemungutan pajak, atau secara serentak membuat perubahan dalam pengeluaran pemerintah dan sistem pemungutan pajak. ${ }^{11}$

Dapat digarisbawahi bahwa kebijakan fiskal secara konvensional dimaksudkan sebagai alat rekayasa pemerintah dalam perekonomian yang menganut mekanisme pasar bebas, yang diharapkan dapat mempengaruhi jalannya aktivitas perkonomian suatu negara. Instrumen kebijakan ini terutama pajak akan berdampak pada terciptanya kondisi perekonomian tertentu. Bagaimana model pertumbuhan ekonomi yang terbentuk sangat bergantung pada kebijakan pemegang otoritas fiskal. Pertumbuhan ekonomi yang tinggi, kesenjangan ekonomi dalam masyarakat ataupun pemerataan pendapatan tidak lepas dari orientasi perilaku para pemegang otoritas fiskal.

\section{Sistem Fiskal Islam}

Dalam perspektif teori ekonomi konvensional, kebijakan fiskal itu dibuat karena terjadinya kegagalan mekanisme pasar (market failure). Kegagalan mekanisme pasar yang terus terjadi akan menimbulkan distorsi atau gangguan dalam hal penawaran dan permintaan yang kemudian dapat mengganggu keseimbangan dari permintaan agregatif (AS) dan penawaran agregatif (AD) pada perekonomian tersebut. ${ }^{12}$ Melalui kebijakan fiskal, penawaran dan permintaan agregat dapat dapat dinaikkan atau diturunkan agar kondisi perekonomian tetap stabil.

Untuk mencapai kesejahteraan masyarakat dalam kestabilan ekonomi yang mantap campur tangan pemerintah secara proporsional dan efektif dalam bentuk kebijakan fiskal yang tepat sangat diperlukan. Adiwarman A. Karim menyebutkan beberapa alasan mengapa pemerintah perlu bermain secara proporsional dalam kegiatan ekonomi antara lain :

\footnotetext{
${ }^{11}$ Sadono Sukirno, Op.Cit., hlm. 188.

12 Adiwarman A. Karim, Ekonomi Makro Islami, Jakarta ; PT RajaGrafindo Persada, 2007, hlm.
} 235. 
- Masyarakat membutuhkan barang-barang yang tergolong public goods (barang yang cenderung tidak dapat diproduksi/ditawarkan secara efisien dalam jumlah sedikit oleh perusahaan swasta sehingga penawarannya kebanyakan dilakukan oleh pihak pemerintah). Public goods akan lebih efisien bila diproduksi bukan oleh perusahaan swasta, tetapi oleh pemerintah.

- Dalam masyarakat terdapat beragam jenis manusia dengan tingkat ketrampilan dan kemampuan ekonomi yang berbeda sehingga secara alamiah terjadi kesenjangan. Untuk itu diperlukan keadilan distribusi sumber daya agar kesenjangan ini dapat diperkecil. Pemerintah harus membantu masyarakat yang kurang beruntung dengan bantuan dari masyarakat yang lebih beruntung. Bantuan dapat dilakukan melalui pajak, sumbangan, hibah atau lainnya.

- Adanya pelayanan-pelayanan vital dagi seluruh warga namun penyelenggaraannya oleh swasta sangat mahal yang tidak terjangkau kalangan tidak mampu, misalnya layanan pendidikan dan kesehatan. Pemerintah mendirikan sekolah-sekolah negeri yang murah atau memberi beasiswa bagi yang kurang mampu dan memberi jaminan kesehatan bagi masyarakat yang kurang mampu. ${ }^{13}$

Kebijakan fiskal sudah dipraktekkan sejak awal terbentuknya masyarakat Muslim yakni sejak zaman Rasulullah dan Khulafaur Rasyidin, dan kemudian dikembangkan oleh para ulama. Ibnu Khaldun (1332-1406 M) misalnya berpandangan bahwa dalam satu kondisi untuk menyeimbangkan ekonomi pemerintah perlu mengecilkan pajak dan meningkatkan pengeluaran pemerintah, karena pemerintah diilustrasikan oleh Ibn Khaldun sebagai pasar terbesar. ${ }^{14}$ Jauh sebelum Ibn Khaldun, Abu Yusuf (731-798 M), sebagaimana dikutip Adiwarman A. Karim, telah menulis secara khusus tentang kebijakan ekonomi dalam kitabnya al-Kharaj, yang menjelaskan tanggung jawab ekonomi pemerintah untuk memenuhi kebutuhan rakyatnya. ${ }^{15}$

Dalam konsep Islam, kebijaksanaan fiskal memiliki arti yang sangat penting dan merupakan salah satu perangkat untuk mencapai tujuan Syariah yakni meningkatkan kesejahteraan dengan tetap menjaga keimanan, kehidupan,

\footnotetext{
13 Ibid., hlm. 236-237

${ }^{14}$ Lihat : Ibn Khaldun, Muqaddimah, Mesir : Mathba'ah Musthafa Muhammad, t.t., hlm. 286

15 Adiwarman A. Karim, Ekonomi Islam Suatu Kajian Kontemporer, Jakarta : Gema Insani Press, 2001, hlm. 25.
} 
intelektualitas, kekayaan dan kepemilikan. ${ }^{16}$ Kebijakan fiskal lebih memegang peranan penting dalam sistem ekonomi Islam bila dibandingkan kebijakan moneter. Adanya larangan tentang riba serta kewajiban tentang pengeluaran zakat menyiratkan tentang pentingnya kedudukan kebijakan fiskal dibandingkan dengan kebijakan moneter. Larangan bunga yang diberlakukan pada tahun Hijriyah keempat mengindikasikan sistem ekonomi Islam yang dilakukan oleh Nabi terutama bersandar kepada kebijakan fiskalnya saja. Sementara itu negara Islam yang dibangun oleh Nabi tidak mewarisi harta sebagaimana layaknya dalam pendirian suatu negara. ${ }^{17}$

Tanggung jawab penyelenggaraan pemerintahan untuk mewujudkan kesejahteraan dan kemaslahatan warga memerlukan anggaran yang memadahi. Di zaman Rasulullah SAW, sumber-sumber penerimaan negara sebagaimana meliputi:

1. Sumber yang tidak terikat. Pada masa awal Rasulullah SAW hijrah ke Madinah, sebagai sebuah negara, Madinah hampir tidak memiliki sumber pemasukan dan pengeluaran negara. seluruh tugas negara dilaksanakan secara gotong royong. Kebutuhan dipenuhi dari berbagai sumber yang tidak terikat. ${ }^{18}$ Pada masa Rasulullah tidak ada tentara formal dengan gaji tetap. Semua Muslim yang mampu boleh menjadi tentara dan berhak mendapat bagian dari rampasan perang. ${ }^{19}$

2. Ghanimah (harta rampasan perang). Ayat yang mengatur alokasi harta rampasan perang (Al-Anfal) turun sesudah terjadi perang Badar pada tahun kedua Hijrah. ${ }^{20}$ Dalam ayat ini ditentukan tata cara pembagian harta rampasan perang sebagai berikut: Seperlima untuk Allah dan Rasul-Nya (seperti untuk negara yang dialokasikan bagi kesejahteraan umum), untuk para kerabat, anak-anak yatim, orang-orang miskin dan para musafir. Seperlima ini dikenal dengan istilah khumus. Sedangkan yang empat perlima bagian lainnya dibagikan kepada para anggota pasukan yang

\footnotetext{
${ }^{16}$ Mustafa Edwin Nasution, et.al., Op.Cit., hlm. 203.

${ }^{17}$ Mustafa Edwin Nasution, et.al., Op.Cit., hlm. 204.

18 Adiwarman Azwar Karim, Sejarah Pemikiran Ekonomi Islam, Edisi Ketiga, Jakarta : PT RajaGrafindo Persada, 2008, hlm. 37.

${ }^{19}$ Munrokhim Misanam, et al., Ekonomi Islam, Jakarta: Rajawali Pers, 2009, hlm. 487.

20 Ibid.
} 
terlibat dalam peperangan. ${ }^{21}$ Ayat tersebut mengindikasikan bahwa dalam sistem ekonomi Islam dikenal adalah sistem proportional tax. Harta rampasan perang dikenakan "pajak" 20 \% $\quad$ (khumus). Dalam menginterpretasikan "ghanimtum min syai" (dari apa saja yang kamu peroleh) dalam ayat tersebut ada perbedaan pendapat di antara para ulama Sunni dan Syi'i. Para ulama Syi'i berpendapat bahwa sumber pendapatan apa saja harus dikenakan kbumus sebesar $20 \%$ sedangkan ulama Sunni memandang ayat tersebut hanya berlaku untuk harta rampasan perang saja. Imam Abu Ubaid, sebagaimana dikutip Adiwarman Azwar Karin, menyatakan bahwa yang dimaksud kbumus itu bukan saja hasil perang tetapi juga barang temuan dan barang tambang. 22

3. Zakat. Pada tahun kedua setelah hijrah sedekah fitrah diwajibkan setiap bulan Ramadhan. Zakat mal mulai diwajibkan pembayarannya pada tahun kesembilan hijrah. Dengan adanya perintah wajib wajib ini, mulai ditentukan para pegawai pengelolanya yang tidak digaji secara rutin tetapi mendapat bayaran tertentu dari dana zakat. ${ }^{23} \mathrm{Di}$ awal-awal masa Islam, zakat dikumpulkan dalam bentuk uang tunai, hasil peternakan dan hasil pertanian. Nishab zakat untuk dinar dan dirham masing-masing 20 dinar dan 200 dirham, zakat yang dikeluarkan sebesar 2,5\% dari jumlah nishab. Jika jumlah pendapatan kurang dari nishab, maka dibebaskan dari zakat. Zakat peternakan dikenakan secara regresif (regressive rate) di mana makin banyak jumlah hewan peliharaan, makin kecil ratenya dan pembedaan ukurannya untuk tiap jenis hewan. Berbeda dengan zakat peternakan, zakat pertanian menggunakan flat rate yang dibedakan antara jenis pengairannya. Bisa jadi karena hasil pertanian merupakan barang yang tidak tahan lama sehingga bila hasil pertaniannya melimpah dikhawatirkan barang tersebut akan menjadi busuk. 24 Pengeluaran zakat telah diatur dalam Alquran Al-Taubah ayat 60 sehingga tidak dapat dibelanjakan untuk pengeluaran umum negara. ${ }^{25}$

${ }^{21}$ Adiwarman Azwar Karim, Op.Cit., hlm. 38-39

22 Adiwarman A. Karim, Ekonomi Makro Islami, Op.Cit., hlm. 264.

${ }^{23}$ Munrokhim Misanam, et.al., Op.Cit., hlm. 487.

24 Adiwarman A. Karim, Ekonomi Makro Islami, hlm. 257.

${ }^{25}$ Munrokhim Misanam, et.al., hlm. 489. 
4. Kharraj. Kharaj atau pajak dipungut dari non-Muslim ketika Khaibar dikuasai pada tahun ketujuh Hijrah. Penduduk Khaibar menentang dan memerangi kaum Muslim. Setelah pertempuran selama sebulan, mereka menyerah. Mereka mengatakan kepada Rasulullah bahwa mereka memiliki pengalaman khusus dalam bertani dan berkebun kurma dan meminta izin untuk tetap tinggal di sana. Rasulullah mengabulkan permintaan mereka. Tanahnya diambil alih oleh orang Muslim dan pemilik lamanya menawarkan untuk mengolah tanah tersebut sebagai pengganti sewa dan bersedia memberikan sebagian hasil produksi kepada negara. Jumlah kharaj dari tanah ini tetap, yaitu setengah dari hasil produksi. Setelah mengurangi sepertiga sebagai kelebihan perkiraan, dua per tiga bagian dibagikan dan mereka bebas memilih; menerima atau menolak pembagian tersebut. Prosedur yang sama juga diterapkan di daerah lain. ${ }^{26}$ Dalam perkembangannya, sebagaimana diungkap Adiwarman Azwar karim, kharaj menjadi semacam pajak tanah seperti pajak bumi dan bangunan (PBB) yang dibayarkan oleh seluruh anggota masyarakat baik orang-orang Muslim maupun orang-orang non Muslim. Berbeda dengan sistem PBB, kharraj ditentukan berdasarkan tingkat produktivitas dari tanah bukan berdasarkan zoning. Yang menentukan jumlah besar pembayaran kharaj adalah pemerintah, dengan mempertimbangkan karakteristik tanah/tingkat kesuburan tanah, jenis tanaman, dan jenis irigasi. ${ }^{27}$

5. Jizyah. Jizyah adalah pajak yang dibayarkan oleh orang non-Muslim khususnya ahli kitab ${ }^{28}$, untuk jaminan perlindungan jiwa, harta atau kekayaan, peribadatan dan tidak wajib militer. ${ }^{29}$ Pada zaman Rasulullah, besarnya jizyah satu dinar per tahun untuk orang dewasa yang mampu membayarnya. Perempuan, anak-anak, pengemis, pendeta, orang tua, penderita sakit jiwa dan semua yang menderita penyakit dibebaskan dari jizyah. Pembayaran tidak harus berupa uang tunai, tetapi dapat juga berupa

${ }^{26}$ Ibid., hlm. 488.

27 Adiwarman A. Karim, Ekonomi Makro Islami, hlm. 257.

${ }^{28}$ Di antara ahli kitab yang terkena kewajiban ini sejauh yang diketahui adalah orang-orang Najran yang beragama Kristen (tahun keenam setelah Hijrah), orang-orang Ailah, Adhruh dan Adhriat membayarnya pada perang Tabuk. Lihat: M.A. Sabzwari, "Sistem Ekonomi dan Fiskal pada Masa Pemerintahan Nabi Muhammad", dalam Adiwarman Karim, (Ed.), Sejarah Pemikiran Ekonomi Islam, Jakarta: IIIT, 2002, hlm. 31.

${ }^{29}$ Munrokhim Misanam, et.al., Op.Cit., 488 
barang atau jasa. ${ }^{30}$ Pada saat perekonomian sedang krisis yang menyebabkan warga negara jatuh miskin, mereka tidak dikenai beban pajak, sebaliknya mereka akan disantuni negara dengan beaya yang diambil dari orang-orang yang kaya. ${ }^{31}$

6. Penerimaan lain. Ada yang disebut kafarat yaitu denda misalnya denda yang dikenakan kepada suami istri yang berhubungan di siang hari pada bulan puasa. Mereka harus membayar denda dan denda tersebut masuk dalam pendapatan Negara. Contoh lain misalnya adalah orang yang meninggal dan tidak mempunyai ahli waris, maka harta warisannya dimasukkan sebagai pendapatan negara. ${ }^{32}$

Penertiban anggaran pendapatan dan belanja negara dilakukan melalui sebuah lembaga yang dikenal dengan Baitul Mal. Baitul Mal berusurusan dengan keuangan publik, merupakan pusat pengumpulan dana atau kekayaan negara untuk pengeluaran tertentu. Pusat pengumpulan dan pembagian daba tersebut adalah Masjid yang didirikan oleh Nabi sesaat setelah hijrah. Pengaturannya fleksibel dan tidak terlalu birokratis. Tidak ada dana yang tidak dibagikan yang berada di penyimpanan. Pada masa Abu Bakar pengaturan Baitul Mal tidak mengalami perubahan. Baru pada masa Umar ada perubahan sistem administrasi akibat bertambahnya pendapatan Muslim, atas saran Homozan, seorang tahanan Persia yang kemudian menerima Islam dan menetap di Madinah. Ia menjelaskan kepada Umar mengenai sistem administrasi yang dilakukan oleh Raja Sasanian. ${ }^{33}$ Ini menunjukkan bahwa pengelolaan keuangan negara merupakan amanat publik yang harus dikelola sebaik-baiknya, dengan mengupayakan cara dan prosedur yang paling praktis dan efektif.

${ }^{30}$ M.A. Sabzwari, Op.Cit., hlm. 31.

31 Mustafa Edwin Nasution, et.al., Op.Cit., hlm. 204

32 Adiwarman A. Karim, Ekonomi Makro Islami, hlm. 266. Mahmud bin Ibrahim menambahkan 'usyur, yaitu pungutan terhadap perdagangan non muslim ahli dzimmi dan ahli harbi yang keluar masuk Negara Islam. Umar bin al-Khattab menetapkan besarnya $10 \%$ atas ahli harbi dan $5 \%$ atas ahli dzimmi. Lihat : Mahmud bin Ibrahim al-Khathib, Al-Nidham al-Iqtishadiyyah fi al-Islam, Riyadl : Maktabah Al-Haramain, 1407 H, hlm. 152.

33 Kadim As-Sadr, "Kebijakan Fiskal pada Awal Pemerintahan Islam," dalam Adiwarman Karim, (Ed.), Sejarah Pemikiran Ekonomi Islam, Jakarta: IIIT, 2002, hlm. 74-75. 
Pengelolaan keuangan negara oleh Rasulullah melalui lembaga Baitul Mal menganut asas anggaran berimbang (balance budget) yakni semua penerimaan habis digunakan untuk pengeluaran negara. Dalam konsep anggaran berimbang, pengeluaran pemerintah sama dengan penerimaannya (equilibrium). ${ }^{34}$ Pemasukan yang sangat sedikit misalnya pada masa Nabi disimpan di Masjid dan dalam waktu yang singkat didistribusikan kepada masyarakat tanpa ada sisa. ${ }^{35}$ Pengeluaran negara pada zaman Rasulullah SAW dan khulafa' al-Rasyidun lebih berorientasi kesejahteraan sosial. Di samping untuk beaya pertahanan dan pengurusan tugas dan administrasi, pengeluaran negara juga untuk tunjangan orang miskin, bantuan bagi penuntut ilmu, pembebasan budak, pembayaran utang orang yang meninggal dalam keadaaan miskin, pembayaran denda atas mereka yang terbunuh secara tidak sengaja oleh pasukan kaum muslimin, bantuan untuk musafir, juga untuk persediaan darurat. ${ }^{36}$

Kebijakan fiskal yang diterapkan pada era permulaan Islam memberikan dampak positif terhadap tingkat investasi, penawaran agregat, dan secara tidak langsung memberikan dampak tingkat inflasi dan pertumbuhan ekonomi. ${ }^{37}$ Kebijakan pertama yang diambil Rasulullah SAW dalam rangka meningkatkan permintaan agregat masyarakat muslim di Madinah setelah hijrah adalah menguatkan persaudaraan Muhajirin dengan Anshar. Setiap Anshar merasa bertanggung jawab atas saudara Muhajirinnya yang menyebabkan terjadinya distribusi pendapatan dari Anshar kepada Muhajirin. Karena orang-orang Muhajirin mempunyai kecenderungan konsumsi yang lebih besar dibandingkan orang-orang Anshar, distribusi pendapatan ini dapat meningkatkan permintaan agregat di Madinah. Di samping itu Rasulullah juga menyediakan lapangan kerja bagi Muhajirin dengan menerapkan kontrak muzara'ab, musaqah, mudlarabah serta kerja sama terbatas antara Muhajirin yang menyediakan tenaga kerja dengan Anshar yang memiliki lahan pertanian, perkebunan dan kekayaan. Perluasan produksi dan fasilitas perdagangan juga

${ }^{34}$ Mohamad Hidayat, Pengantar Ekonomi Islam, Jakarta: Pusat Komunikasi Ekonomi Syariah, 2009, hlm. 116.

35 M.A. Sabzwari, Op.Cit., hlm. 38

36 Adiwarman A. Karim, Ekonomi Makro Islami, Op.Cit., hlm. 275-276. Lihat pula: Mohamad Hidayat, Op.Cit., hlm. 116.

${ }^{37}$ Adiwarman A. Karim, Ekonomi Makro Islami, Op.Cit., hlm. 247. 
meningkatkan produksi total kaum Muslimin dan menghasilkan peningkatan pemanfaatan sumber daya tenaga kerja, lahan dan modal. Di samping itu pembagian harta rampasan perang juga meningkatkan kekayaan dan pendapatan kaum Muslimin yang pada akhirnya meningkatkan permintaan agregat. ${ }^{38}$ Kebijakan membagikan $80 \%$ harta rampasan perang mendorong peningkatan pendapatan yang pada akhirnya meningkatkan permintaan agregatif (AD). Demikian juga kebijakan pemungutan pajak terhadap setiap jenis usaha berhasil menciptakan kestabilan harga dan mengurangi inflasi. Pada saat stagnasi dan menurunnya permintaan agregatif $(\mathrm{AD})$ dan penawaran agregatif (AS), pajak (khususnya kbums) mendorong stabilitas pendapatan dan produksi total. Kebijakan ini juga tidak menyebabkan penurunan harga maupun jumlah produksi. ${ }^{39}$

Kebijakan fiskal Islam tidak sama dengan kebijakan pemungutan pajak/upeti yang umum dipraktikkan para raja/kaisar. Pengumpulan kekayaan warga serta upeti dari wilayah yang ditaklukkan lebih diorientasikan untuk kebesaran dan kekayaan kalangan istana. M.A. Sabzwari mencatat bahwa keuangan menjadi puncak kebesaran suatu kerajaan di seluruh dunia. Perhatian terbesar penguasa tertuju pada pengumpulan dan penerimaan kerajaan. Raja Edward misalnya, menyimpan harta kekayaan kerajaan di kamar tidurnya sampai ia meninggal. Pada masa Henry I (1068-1135) dibuat kantor pemerintahan bagi bendahara raja dan pada masa Henry II (1133-1189) bendahara raja sudah memiliki rumah sendiri di Westminster. Gelar Chamberlain (bendahara negara) berasal dari kata king's chamber (ruang tidur raja). Contoh kondisi keuangan negara tersebut terjadi di Inggris yang dikatakan sebagai pemerintahan terbaik ketika itu dan negara paling tertib di seluruh Eropa Barat. ${ }^{40}$ Pengelolaan keuangan di era permulaan Islam ada pada lembaga Baitul Mal. Baitul Mal di daerah diberi wewenang mengelola keuangan di daerah yang bersangkutan. Kalau ada surplus baru diberikan ke Baitul Mal pusat. Ini menunjukkan bahwa semangat otonomi daerah sudah dilaksanakan di zaman awal Islam. ${ }^{41}$

\footnotetext{
${ }^{38}$ Kadim As-Sadr, Op.Cit., hlm. 112-113.

39 Adiwarman A. Karim, Ekonomi Makro Islami, Op.Cit., hlm. 251.

${ }^{40}$ M.A. Sabzwari, Op.Cit., hlm. 37

${ }^{41}$ Mohamad Hidayat, Op.Cit., hlm. 115.
} 
Kebijakan fiskal Islam tidak identik dengan kebijakan fiskal modern. Tidak seperti kebijakan fiskal dalam teori ekonomi konvensional di mana suatu pemerintahan dapat mempengaruhi kegiatan perekonomian melalui pengubahan insentif dalam tarif pajak maupun besarnya "tax base" dari suatu kegiatan perekonomian, maka dalam sistem fiskal Islam salah satu instrumennya seperti zakat sudah ditentukan mengenai segala ketentuan tentang besarnya tarif berdasarkan petunjuk dari Rasulullah. Kebijakan zakat dalam fiskal Islam sangat berbeda dengan kebijakan perpajakan. Zakat berusaha mempertemukan pihak surplus ekonomi (aghniya) dengan pihak defisit (fuqara). Instrumen ini diproyeksikan pada sasaran pemerataan pendapatan antara surplus dan defisit atau bahkan menjadikan kelompok yang defisit/pihak yang berhak menerima zakat (mustabik) menjadi surplus/pihak yang wajib zakat (murakki).42

Antara zakat dalam fiskal Islam dengan pajak dalam fiskal konvensional memiliki dampak yang berbeda dalam perekonomian. Adiwarman A. Karim mencatat beberapa poin kebijakan fiskal Islam yang cukup maju dan berhasil menciptakan tata keseimbangan ekonomi, antara lain bahwa sistem perhitungan zakat perdagangan yang berdasarkan keuntungan (profit atau quasi rent) tidak mempengaruhi kurva penewaran sehingga jumlah barang yang ditawarkan tidak berkurang dan tidak terjadi kenaikan harga jual. Ini berbeda dengan sistem pajak pertambahan nilai (PPN) dimana pengenaan pajak terhadap harga jual akan menyebabkan berkurangnya penawaran barang di pasar dan harga akan naik. ${ }^{43}$ Dalam buku Ekonomi Islam yang ditulis oleh Pusat Pengkajian dan Pengambangan Ekonomi Islam UII Yogyakarta, disebutkan pembahasan matematis mengenai perbandingan antara pengenaan pajak dan kewajiban zakat. Pembahasan ini di samping menyimpulkan bahwa hampir semua pajak mempunyai sifat meningkatkan biaya produksi dan harga jual barang, juga menegaskan bahwa zakat lebih baik dari pada pajak dilihat dari kemampuannya mempertahankan tingkat kesejahteraan masyarakat. ${ }^{44}$

Jika kebijakan fiskal dalam ekonomi konvensional yang bersendikan sistem pasar dimaksudkan untuk mengoreksi jalannya perekonomian agar

\footnotetext{
${ }^{42}$ Mustafa Edwin Nasution, et.al., Op.Cit., hlm. 207-208.

43 Adiwarman A. Karim, Ekonomi Makro Islami, Op.Ciy..hlm. 248-249.

44 Munrokhim Misanam, et.al., Op.Cit., hlm. 518-519.
} 
mekanisme pasar "bebas" berjalan sempurna, maka dalam sistem ekonomi Islam kebebasan pasar terikat oleh moralitas Islam seperti persaingan yang sehat (fair play), kejujuran (honesty), keterbukaan (transparancy) dan keadilan (justice). 45 Kontrol pasar berarti menjaga agar para pelaku pasar tetap menjunjung tinggi prinsip-prinsip moralitas tersebut. Kontrol negara terhadap mekanisme pasar ini bukan melalui lembaga Baitul Mal/kebijakan fiskal tetapi melalui lembaga yang disebut dengan al-hisbah. Rasulullah sendiri menjalankan fungsi sebagai market supervisor atau al-hisbah yang kemudian menjadi acuan bagi peran negara dalam menjamin berjalannya mekanisme pasar secara sempurna. ${ }^{46}$

Instrumen kebijakan fiskal sebagaimana dipraktikkan pada era permulaan Islam lebih diorientasikan ke arah disribusi kekayaan yang berkeadilan. Hakikat permasalahan ekonomi terletak pada bagaimana distribusi harta dan jasa di tengah-tengah sehingga titik berat pemecahan permasalahan ekonomi adalah bagaimana menciptakan suatu mekanisme distribusi ekonomi yang adil, yang urgensinya disebutkan dalam Al-Qur'an (QS Al-Hasyr 7). ${ }^{47}$ Dalam konsep ekonomi Islam, kebijaksanaan fiskal bertujuan untuk mengembangkan suatu masyarakat yang didasarkan atas distribusi kekayaan berimbang dengan menempatkan nilai-nilai material dan spiritual pada tingkat yang sama. ${ }^{48}$

Berbagai instrumen dan aplikasi kebijakan fiskal Islam dilandasi oleh prinsip-prinsip Islam yang berkenaan dengan belanja publik. Mengacu pada alqawaid al-fiqhiyyah, Umer Chapra merumuskannya menjadi enam prinsip. Pertama, kriteria pokok bagi semua alokasi pengeluaran adalah sejahteranya masyarakat. Kedua, penghapusan kesulitan hidup dan penderitaan harus diutamakan di atas penyediaan kenyamanan. Ketiga, kemaslahatan mayoritas yang lebih besar harus didahulukan daripada kemaslahatan minoritas yang lebih sempit. Keempat, suatu pengorbanan atau kerugian privat dapat ditimpakan untuk menyelamatkan pengorbanan dan kerugian public, dan suatu pengorbanan atau kerugian yang lebih besar dapat dihindarkan dengan memaksakan pengorbanan atau kerugian yang lebih kecil. Kelima, siapapun

\footnotetext{
45 Ibid., hlm. 301.

46 Ibid., hlm., 342.

${ }^{47}$ Mustafa Edwin Nasution, et.al., Op.Cit., hlm. 204-205.

48 Ibid., hlm. 206.
} 
yang menerima manfaat harus bersedia menanggung biaya. Keenam, sesuatu di mana tanpa sesuatu tersebut kewajiban tidak dapat terpenuhi maka sesuatu itu hukum wajib. ${ }^{49}$

Mengacu pada praktik di masa Rasulullah, dapat digarisbawahi bahwa kebijakan fiskal Islam merupakan kebijakan keuangan publik terkait dengan prinsip penyelenggaraan negara untuk kemaslahatan umat. Seluruh warga negara bagaikan berada dalam satu keluarga besar. Ada rasa sepenanggungan dan saling menjamin (takaful). Zakat misalnya berorientasi pada sikap saling berbagi, diambil dari yang berlebih diberikan kepada yang kekurangan. Jizyah merupakan wujud kebersamaan masyarakat non Muslim dalam kehidupan bernegara sebagai perwujudan rasa sepenanggungan. Kharaj juga berorientasi pada distribusi kekayaan yang adil di masyarakat.

Berbagai bentuk kebijakan Rasulullah yang terkait fiskal adalah representasi prinsip-prinsip belanja publik dalam konteks politik, ekonomi dan sosial waktu itu. Sebagai sebuah agama, Islam mengemban misi kesejahteraan lahir batin umat manusia dengan distribusi kekayaan yang berkeadilan. Dapat dikatakan bahwa ghanimah, fai', kharaj dan sumber-sumber belanja publik lainnya adalah dialektika pencapaian misi tersebut dengan realitas kehidupan sosial, politik dan ekonomi kala itu, dan merupakan bentuk kompromi dengan realitas kondisi sosiologis menuju cita-cita ideal ekonomi Islam.

Kondisi sosial politik yang tidak sama dengan masa Rasulullah SAW mengharuskan perlunya "ijtihad" politik ekonomi Islam di era kontemporer iniagar kebijakan fiskal yang diberlakukan tetap dapat merepresentasikan prinsip-prinsip fiskal Islam. Kebijakan perpajakan yang memperlebar kesenjagan ekonomi masyarakat serta pungutan pajak yang melemahkan semangat kreativitas usaha kecil adalh bentuk kebijakan fiskal yang kontraproduktif dengan misi Islam di bidang ekonomi.

${ }^{49}$ M. Umer Chapra, The Future of Economics : An Islamic Perspective, terj. Ikhwan Abidin, "Masa Depan Ilmu Ekonomi : Sebuah tinjauan Islam," Jakarta : Gema Insani Press, 2001, hlm. 287-288. 


\section{Kesimpulan}

Kebijakan fiskal memegang peranan yang sangat penting dalam menunjang kestabilan ekonomi suatu negara. Peranannya tidak hanya sekedar untuk kelancaran pembelanjaan negara saja, tetapi memiliki dampak yang yang terkait dengan aktivitas ekonomi secara makro di suatu negara. Dalam konsep ekonomi Islam yang tidak mengenal riba, kebijakan fiskal lebih menjadi tumpuan dalam menstabilkan perekonomian dari pada kebijakan moneter.

Keberhasilan kebijakan fiskal pada masa awal Islam pada dasarnya karena pemegang kebijakan mampu menerapkan berbagai instrumen kebijakan fiskal yang mengacu pada ajaran Islam secara tepat sesuai kondisi sosial, politik dan ekonomi yang ada waktu itu. Namun penerapan kebijakan fiskal waktu itu tidak serta merta mudah diterapkan untuk masa sekarang karena kendala, politik, sosial maupun kondisi perekonomian global yang cukup dominan. Maka penerapan kebijakan fiskal, meski tidak bisa sama persis sebagaimana yang digunakan pada masa awal Islam, perlu berpegang pada prinsip-prinsip Islam tentang penerimaan dan pengeluaran negara yang berorientasi pada kesejahteraan dan distribusi kekayaan yang adil dalam masyarakat.

Wa Allah A'lam bi Al-Shawab

Volume IV/Edisi 1/Mei 2013 
Konsep Fiskal Islam dalam Perspektif Historis

\section{DAFTAR PUSTAKA}

Chapra, M. Umer Chapra, The Future of Economics : An Islamic Perspective, terj. Ikhwan Abidin, Masa Depan Ilmu Ekonomi : Sebuah tinjauan Islam, Jakarta : Gema Insani Press, 2001.

Hidayat, Mohamad, Pengantar Ekonomi Islam, Jakarta: Pusat Komunikasi Ekonomi Syariah, 2009.

Ibn Khaldun, Waliyyuddin 'Abdurrahman ibn Muh\}ammad. al-Muqaddimah. Mesir: Mat\}ba'ah Mus $\}$ afa Muhammad, t.t.

Karim, Adiwarman A., , Ekonomi Makro Islami, Jakarta ; PT RajaGrafindo Persada, 2007.

Karim, Adiwarman A., Ekonomi Islam Suatu Kajian Kontemporer, Jakarta : Gema Insani Press, 2001.

Karim, Adiwarman A., Sejarah Pemikiran Ekonomi Islam, Jakarta : IIIT, 2002.

Karim, Adiwarman Azwar, Sejarah Pemikiran Ekonomi Islam, Edisi Ketiga, Jakarta : PT RajaGrafindo Persada, 2008.

Al-Khathib, Mahmud bin Ibrahim, Al-Nidham al-Iqtishadiyyah fi al-Islam, Riyadl : Maktabah Al-Haramain, $1407 \mathrm{H}$.

Kuper, Adam dan Kuper, Jessica, The Social Science Encyclopedia, second edition, New York : Routledge, 2001.

Misanam, Munrokhim, et al., Ekonomi Islam, Jakarta: Rajawali Pers, 2009.

Nasution, Mustafa Edwin, et.al., Pengenalan Ekslusif Ekonomi Islam, Jakarta: Kencana, 2007.

Pass, Christopher \& Bryan Lowes, Collins Dictionary of Economics, terj. Tumpal Rumapea \& Posman Haloho, "Kamus Lengkap Ekonomi", Edisi Kedua, Jakarta: Penerbit Erlangga, 1994.

Rahman, Afzalur, Economic Doctrines in Islam, terj. Soeroyo, Nasta'in, Doktrin Ekonomi Islam, Jilid III, Jakarta : Dana Bhakti Wakaf, 1995.

Sukirno, Sadono, Makroekonomi Teori Pengantar, Edisi Ketiga, Jakarta : PT RajaGrafindo Persada, 2006. 